\title{
Reuse of Brick Waste as a Cheap-Sorbent for the Removal of Nickel Ions from Aqueous Solutions
}

\author{
Teba H. Mhawesh and Ziad T. Abd Ali
}

University of Baghdad/ College of Engineering/ Environmental Engineering, Baghdad Iraq

\begin{abstract}
The potential application of granules of brick waste (GBW) as a low-cost sorbent for removal of $\mathrm{Ni}^{+2}$ ions from aqueous solutions has been studied. The properties of GBW were determined through several tests such as X-Ray diffraction (XRD), Energy dispersive X-ray (EDX), Scanning electron microscopy (SEM), and BET surface area. In batch tests, the influence of several operating parameters including contact time, initial concentration, agitation speed, and the dose of GBW was investigated. The best values of these parameters that provided maximum removal efficiency of nickel $(39.4 \%)$ were $1.5 \mathrm{hr}, 50 \mathrm{mg} / \mathrm{L}, 250 \mathrm{rpm}$, and $1.8 \mathrm{~g} / 100 \mathrm{~mL}$, respectively. The adsorption data obtained by batch experiments subjected to the Three isotherm models called Langmuir, Freundlich and Elovich, The results showed that the Freundlich isotherm model described well the sorption data $\left(\mathrm{R}^{2}=0.9176\right)$ in comparison with other models. The kinetic data were analyzed using two kinetic models called pseudo-first-order and pseudo-second-order. The pseudo-first-order kinetic model was found to agree well with the experimental data.
\end{abstract}

Keywords: Sorption, $\mathrm{Ni}^{+2}$, brick waste, Isotherms, Kinetics, Wastewater

Received on 13/10/2019, Accepted on 18/02/2020, published on 30/06/2020

https://doi.org/10.31699/IJCPE.2020.2.3

\section{1- Introduction}

Many branches of industry nowadays generate large quantities of wastewater containing toxic and carcinogenic organic and inorganic compounds. Heavy metals are considered inorganic pollutants such as mercury, cadmium, lead, cobalt, zinc, nickel, manganese etc. It's not decomposed so their metal concentrations should be at minimum to reasonable levels before drain into their environment, [1].

Nickel metals are danger and toxic to humans, it's represent a serious environmental issue, [2]. Nickel exists in the effluents of storage battery industries; desalinate plants, gas turbines, coinage, and costume jewelry, [3].

The US Environmental Protection Agency (EPA) requires nickel metals not to exceed $0.015 \mathrm{mg} / \mathrm{L}$ in drinking water, [4].

Above the permissible limit may cause adverse health impacts such as anemia, diarrhea , hepatitis, the damages of lungs and kidney and pulmonary fibrosis,[5];[2].

Accordingly, many methods have been studied to remove toxic metal ions from industrial wastewater include, chemical-precipitation, ion-exchange, biosorption , reverse-osmosis, floatation, and sorption etc. $[2],[6]$.
Several sorbents can be utilized for removal of toxic metals from wastewater but porous carbons sorbent are utilized extensively in contrast with other methods because these sorbents have a large specific, high sorption capacity, and easily regenerated, but is considered an expensive sorbent material.

For that reason, different cheap materials like: zeolites, [7], metal oxides, [8], iron oxide-coated sand, [9], and clay minerals, [10], had recently been examined with the purpose to demonstrate their capacity for heavy metal removal from pollutants wastewater. But, the solution of specific water issues encountered in communities of developing countries had required the elaboration of proven and locally more suitable water - handling procedures at low costs, [11].

In the recent years, the ability of brick waste utilized as a cheap sorbent to remove soluble heavy metal pollutants from wastewaters had been studied, [12, [13].

The nature of brick material, surface area, and surface charge influence the extent of interaction with metal ions.

As brick granules are negatively charged, therefore cations will be strongly attached to brick granules [14].

Based on the above mentioned concepts, the purpose of this study is to use brick waste as a cheap and abundant material to remove nickel ions from aqueous solutions.

The influence of contact time, initial concentration of $\mathrm{Ni}^{+2}$, agitation speed, and sorbent mass on the removal percent of nickel ions were studied. 


\section{2- Experimental work}

\subsection{Granules of Brick Waste (GBW) Preparation}

Pieces of brick waste, which are left unused after construction, were used as sorbent in this study. It were crushed and sieved with size ranging from (1.18) $\mathrm{mm}$ to (1.7) $\mathrm{mm}$.

The obtained granules of GBW were washed several times with distilled water then dried as shows in Fig. 1.

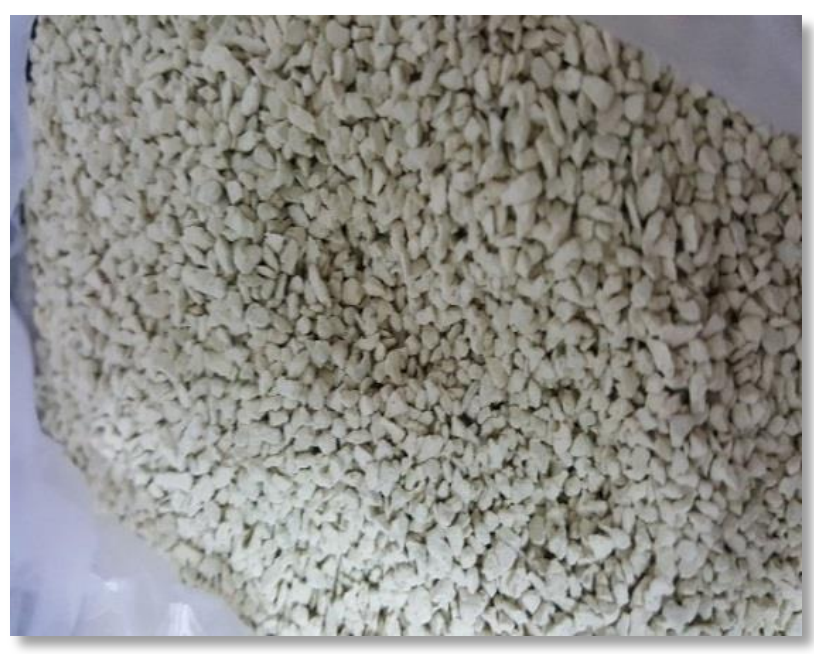

Fig. 1. Granules of brick waste (GBW)

\subsection{Characterization of GBW}

\section{a. Surface Area}

Surface area is an important factor in determining the active sites that will be occupied with the contaminants. Therefore, increasing the surface area of the material increases its susceptibility to adsorb more quantity of pollutants. The BET surface area was measured using (Quanta chrome, USA), at the Petroleum Research and Development Center/ Ministry of Oil / Baghdad - Iraq.

\section{b. X-Ray Diffraction (XRD) Analysis}

The surface qualitative analysis was carried out to characterize and confirm the existence of the major components; samples were analyzed before uptake of nickel. This analysis was accomplished using (BRUKER, D2 PHASER, Germany).

\section{c. Energy Dispersive X-ray (EDX) Analysis}

EDX analysis is a chemical microanalysis technique utilized in conjunction with scanning electron microscopy (SEM).It's used to recognize the elemental composition of materials. This test carried out using ( TESCAN,Vega III , Czech Republic). d. Scanning Electron Microscopy (SEM)

Scanning Electron Microscope (TESCAN, Vega III, and Czech Republic) was utilized for the surface studies of GBW. Using the optimized conditions for the sorption of nickel ions, the loaded mass was filtered, washes and dried at $105{ }^{\circ} \mathrm{C}$ for $30 \mathrm{~min}$. Unloaded mass was also subject to the same circumstances and both the loaded and unloaded mass was subjected to SEM to identify the changes on the surface of the GBW before and after loading by the nickel ions molecules.

\subsection{Preparation of Synthetic Wastewater}

The synthetic solution of nickel with a concentration of $1000 \mathrm{mg} / \mathrm{L}$ was prepared by dissolving a $4.95 \mathrm{~g}$ of of nickel nitrate $\left(\mathrm{Ni}\left(\mathrm{NO}_{3}\right) \cdot 6 \mathrm{H}_{2} \mathrm{O}\right)$ in $1 \mathrm{~L}$ of distilled water and this synthetic solution was $\mathrm{pH}$ adjusted using $0.1 \mathrm{M}$ of ( $\mathrm{HNO} 3$ ) and/or $(\mathrm{NaOH})$ as required.

\subsection{Sorption Experiments}

These experiments were carried out to identify the better conditions of contact time, , initial concentration of contaminant, agitation speed and dosage of sorbent. A number of flasks of $(250 \mathrm{ml})$ are employed and each one is filled with $100 \mathrm{ml}$ of $\mathrm{Ni}^{2+}$ ions solution which has initial concentration of $(50 \mathrm{mg} / \mathrm{l})$, initial $\mathrm{pH}=4$ and about $(1 \mathrm{~g} / 100 \mathrm{ml})$ of sorbent $(\mathrm{GBW})$ was added into each flask .The flasks were preserved stirred in $(200 \mathrm{rpm})$ speed orbital shaker at ambient temperature. Then the GBW was separated from the pollutant solution by filtration.

These tests were conducted at different time $(10,20,30,50,70,90,150,180,240 \quad \min ),$.$\quad initial$ concentrations $(50,100,150,200,250 \mathrm{mg} / \mathrm{l})$, agitationspeeds $(0,50,100,150,200$ and $250 \mathrm{rpm})$, and sorbent dosages $(0.2,0.4,0.6,0.8,1,1.1,1.2,1.3,1.5,1.8$ and 2 $\mathrm{g} / 100 \mathrm{ml})$.

The metal ion concentration at saturation was calculated by atomic absorption spectrometry (Shimadzu, Japan). The concentration of metal ion sorbed by GBW was calculated from the difference between the initial and ,the final concentration of metal ions solution obtained before and after contact between the GBW and the synthetic $\mathrm{Ni}^{+2}$ solution. The sorption capacities were determined using Eq. (1) [15]:

$q e=\frac{(\mathrm{Co}-\mathrm{Ce}) V}{m}$

Where: $q e$ is the amount of sorbed nickel ion, per unit mass of $\mathrm{GBW}(\mathrm{mg} / \mathrm{g}), C o$ and $C e$ are the initial and equilibrium concentrations of nickel in the solution $(\mathrm{mg} / \mathrm{L}), V$ is the volume of solution (L), and $m$ is the mass of the sorbent GBW $(\mathrm{g})$. The removal efficiency $(R \%)$ of the $\mathrm{Ni}^{+2}$ was calculated using Eq. (2), [15]:

$R \%=\frac{C o-C e}{C o} \times 100$ 


\section{3- Isotherm Models}

In the current study, three isotherm models is used to simulate the performance of GBW in removing nickel ions from wastewater. A summary of these models is presented below:

- Langmuir model: assumes a surface witle homogeneous binding sites, equivalent sorption energies, and no interactions between sorbed species, [16] . The linear form of this model can be written as follows:

$\frac{C e}{q e}=\frac{C e}{q \max }+\frac{1}{q \max K \mathrm{~L}}$

\section{Where:}

qmax , is the maximum sorption capacity $(\mathrm{mg} / \mathrm{g})$.

$K L$, is the Langmuir sorption constant $(\mathrm{L} / \mathrm{mg})$.

$\mathrm{Ce}$, is the concentration $(\mathrm{mg} / \mathrm{L})$ of $\mathrm{Ni}^{+2}$ in solution at equilibrium.

The plot of $(\mathrm{Ce} / q e)$ against $(\mathrm{Ce})$ gives a straight line with a slope and intercept of (1/qmax) and (1/qmax KL) respectively.

- Freundlich model: It's an empirical model not limited to monolayer coverage alone but also describe multilayer adsorption, [16]. It is expressed linearly as in Eq.4:

$\ln \mathrm{qe}=\frac{1}{\mathrm{n}} \ln \mathrm{Ce}+\ln \mathrm{KF}$

Where: $K F$, is the Freundlich sorption constant.

$\mathrm{Ce}$, is the concentration $(\mathrm{mg} / \mathrm{L})$ of $\mathrm{Ni}^{+2}$ in solution at equilibruim.

$n$, is an empirical constant indicative of the intensity of the sorption.

The Plots of $(\log q e)$ against, $(\log C e)$, gives a linear graph with slope $1 / n$ and intercept $\log K F$ from which $\mathrm{n}$ and $K F$ can be determined respectively.

- Elovich model: is based on a kinetic principle assuming that the sorption effective sites increase exponentially with sorption, which implies a multilayer sorption, [17], [18]. It can be expressed as:

$\ln \frac{q e}{C e}=\ln K E q m-\frac{q e}{q m}$

Where: $K E$ is the Elovich equilibrium constant $(\mathrm{L} / \mathrm{mg})$ and $q m$ is the Elovich maximum adsorption capacity (mg/g).

\section{4- Kinetic Models}

Kinetic sorption models are helpful to understand the mechanism of the sorption process of nickel onto GBW. These models include pseudo first order and pseudosecond order, [19].

The pseudo-first order kinetic rate equation is :

$\ln (q e-q t)=\ln (q e)-K_{1} t$

Where: $q e$ and $q t$, represent the amounts of metal ion $\left(\mathrm{Ni}^{+2}\right)$ sorbed per unit mass of GBW at equilibrium $(\mathrm{mg} / \mathrm{g})$ , and time $t$ ( $\mathrm{min})$, respectively.

$K_{l}$, is the rate constant of pseudo_ first _ order sorption (1/min). The pseudo_second_order kinetics rate equation is:

$\frac{t}{q t}=\frac{1}{K_{2} q e^{2}}+\frac{t}{q e}$

Where: $K_{2}$, is the rate constant of pseudo_second_order sorption ( $\mathrm{g} / \mathrm{mg}$. min).

\section{5- Results and Discussion}

\subsection{Characterization of GBW}

\section{a. XRD Analysis}

The XRD measurement was performed to identify the mineralogical composition of GBW. Fig. 2 illustrates that GBW was composed mainly of Diopside (29.9\%), Quartz (22.4\%), wollastonit (22.2\%), akermente (20.5\%) and Mellite $(5 \%)$. Diopside Originating from dolomite $\left(\mathrm{CaO}, \mathrm{MgO}, 2 \mathrm{CO}_{2}\right)$, also explain that (quartz) and (calcite) are the most popular compounds, with the addition of clays and clay minerals. However, due to the application of high temperature handling through the manufacturing process, the decomposition of clay minerals forming $\left(\mathrm{SiO}_{2}\right)$ compound, which followed by the loss of their crystal structure. $\mathrm{CaCO}_{3}$ compound decompose and resulting $\mathrm{CaO}$ compound that may react with the clay resulting calcium-silicate called wollastonite [20].

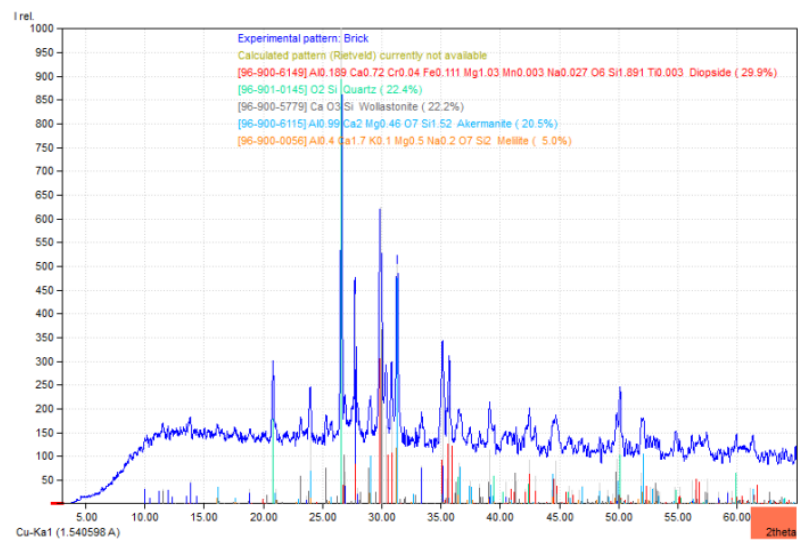

Fig. 2. XRD of GBW 


\section{b. EDX Analysis}

The EDX analysis was carried out and the spectra are given in Fig. 3. This figure indicates that the GBW composed of oxygen, calcium ,Silicon, aluminium, iron , magnesium, sodium, potassium and sulfur, with percentage of $44.2 \%, 21.7 \%, 18.1 \%, 5.7 \%, 5 \%, 2.8 \%$, $1.4 \%, 0.6 \%$ and $0.6 \%$, respectively.

The analysis for GBW showed the presence of oxygen, calcium, silicon, and other small percentages of metals .The existence of these oxides and hydroxides in GBW because its having a various (higher) sorption capacity , [21].

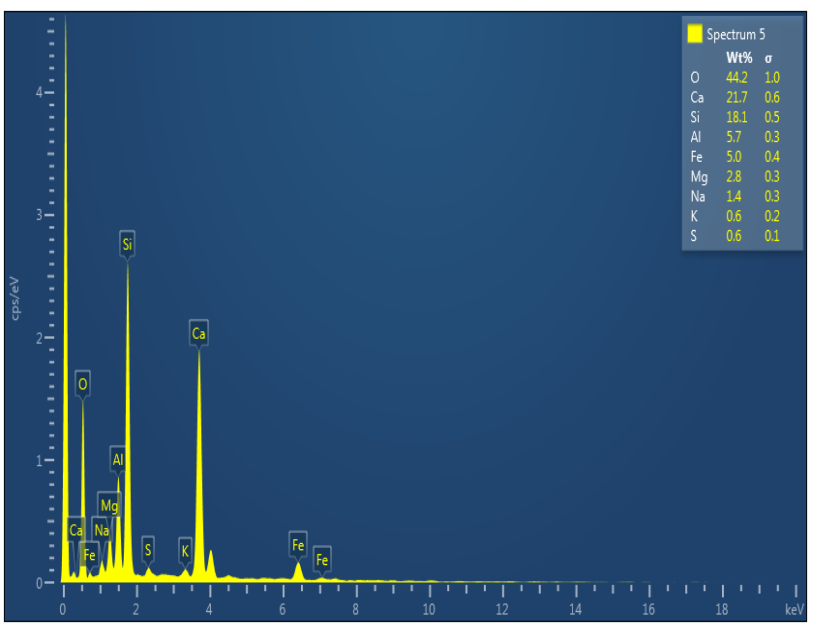

Fig. 3. EDX spectra of GBW

\section{c. SEM Analysis}

The SEM analysis images at $50 \mathrm{Mm}$ gained before/after sorption to identify the surface morphology. Fig. 4 (a) represents the SEM spectra of the GBW before nickel loading, its shows irregular structure having small pores, which simplify the process of sorption.

The SEM analysis after nickel sorption indicates that these pores become filled with nickel ions as shown in Fig. 4 (b) [21].

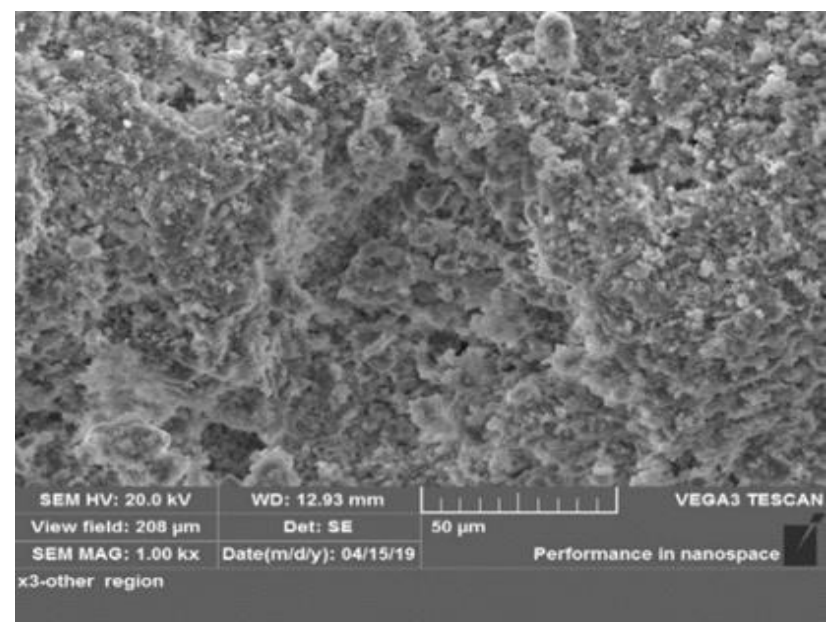

(a)

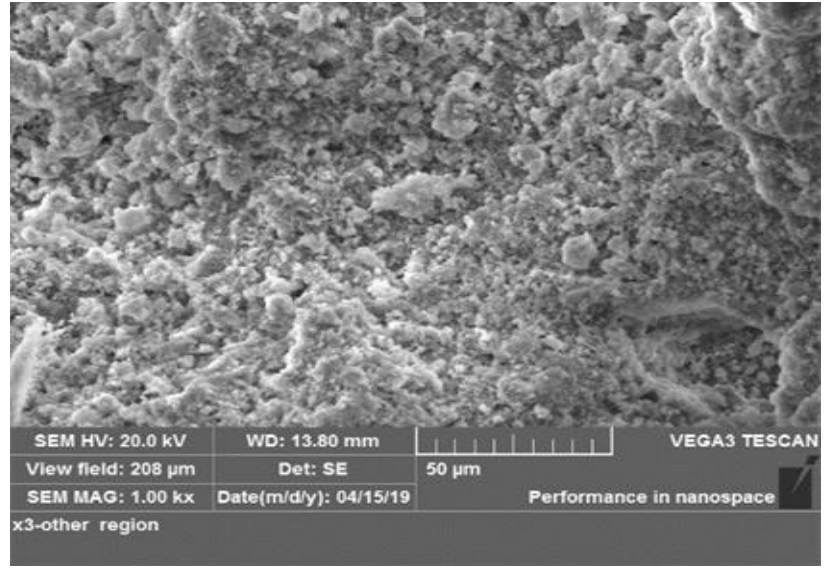

(b)

Fig. 4. SEM spectra of the of GBW (a) before and (b) after nickel ions loading

\section{d. Surface Area}

The results of this test clarify that the GBW sample show a low BET surface area of $\left(1 \mathrm{~m}^{2} /\right.$ g).this results in a good agreement with previous study of Kooli [22].

\subsection{Influence of Batch Operating Parameters}

\section{a. Effect of Contact Time}

The impact of the contact time on sorption of $\mathrm{Ni}^{+2}$ using GBW was studied by using contaminated aqueous solution with initial nickel concentration $50(\mathrm{mg} / \mathrm{L})$ at $\mathrm{pH}=4$. The relation between the contact time and removal efficiency of nickel ions is shown in Fig.5,the best removal efficiency (28\%) was reached within about $90(\min )$. The sorption of $\mathrm{Ni}^{+2}$ ions occurred in two phase, an initial rapid sorption followed by subsequent slow sorption. The sorption process appeared to proceed rapidly when the numbers of active sites are much higher than the number of metal species to be sorbed, [23].

The increase of solution $\mathrm{pH}$ during the contact with GBW can be attributed to the dissolution of some of their components, [20].

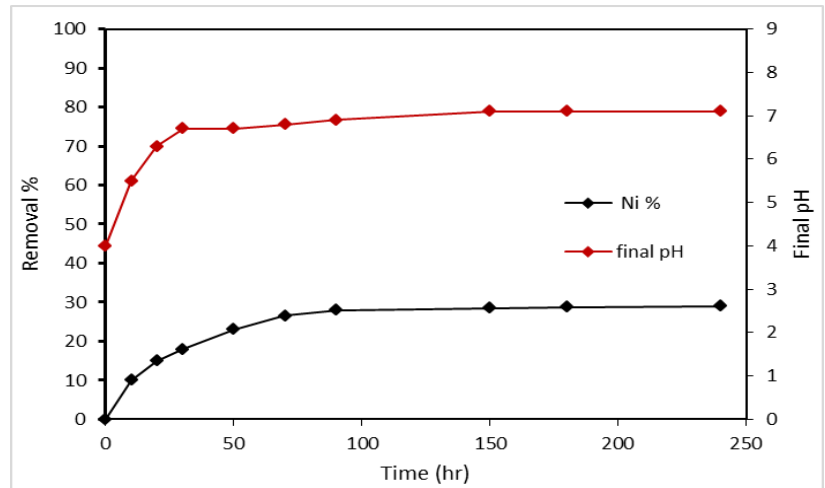

Fig. 5. Effect of contact time on $\mathrm{Ni}^{+2}$ removal percent $(\mathrm{Co}$ $=50 \mathrm{mg} / \mathrm{L}, \mathrm{pH}=4$, agitation speed $=200 \mathrm{rpm}$, and mass of $\mathrm{GBW}=1 \mathrm{~g} / 100 \mathrm{ml}$ ) 


\section{b. Effect of Initial Concentration}

The initial metal ions concentration is a very important factor to be investigated in sorption studies as most contaminated wastewaters usually present different concentrations of metal ions, so determination of its effect is necessary for an elaborate sorption study, [24].

The effect of initial metal ion concentration on the percentage removal of $\mathrm{Ni}^{+2}$ ions using GBW is shown in Fig. 6. The percentage removal of metal ions decreased with increase in the initial metal concentration from 50 to $250 \mathrm{mg} / \mathrm{L}$. A decrease from $28 \%$ to $9 \%$ of $\mathrm{Ni}^{+2}$ ions was obtained. This decrease is due to the fact that the sorbent material (GBW) has a fixed number of active sites and at higher concentrations, the active sites become saturated, [25]

The simple hydrolysis of generality divalent metal ions can be written as follows:

$\mathrm{M}^{+2}+\mathrm{H}_{2} \mathrm{O} \rightleftharpoons \mathrm{M}(\mathrm{OH})^{+}+\mathrm{H}^{+}$

Where: $\mathrm{M}^{+2}$ is $\mathrm{Ni}^{+2}$ or any metal ions. The final $\mathrm{pH}$ increase when the concentration of the solution decreases.

This happens when GBW is being occupied by $\mathrm{Ni}^{+2}$ ions, the reaction above shifts to the left, leading to the depletion of protons and hence rise in $\mathrm{pH},[\mathbf{2 6}]$

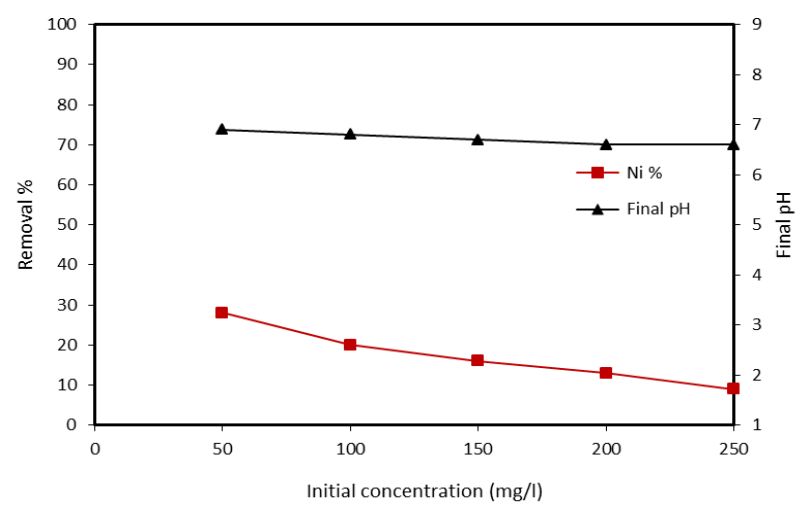

Fig. 6. Effect of initial concentration on $\mathrm{Ni}^{+2}$ removal percent (Time $=90$ min., $\mathrm{pH}=4$, agitation speed $=200$ rpm, and mass of GBW = $1 \mathrm{~g} / 100 \mathrm{ml}$ )

\section{c. Effect of Agitation Speed}

The effect of agitation speed of the sorbent/sorbate system was monitored at (0, 50, 100, 150, 200, and 250 $\mathrm{rpm})$ as shown in Fig.7.The significant increase in sorption is primarily due to the fact that agitation speed facilitates proper contact between $\mathrm{Ni}^{+2}$ ions in solution and the GBW effective sites and consequently promoting better transfer of sorbate ions $\left(\mathrm{Ni}^{+2}\right)$ to the sorbent sites, [27].In addition, the increase of the $\mathrm{pH}$ of the solution during the contact with GBW can be attributed to the dissolution of some GBW components as reported by Jelić ,[20].

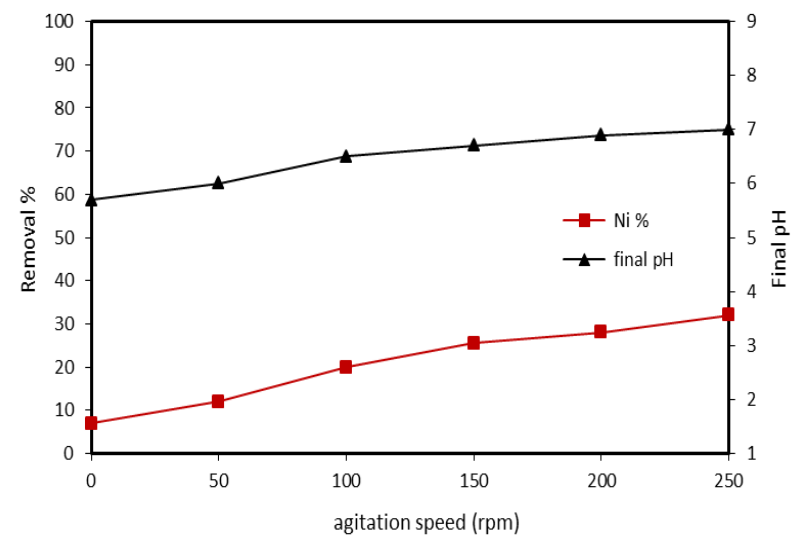

Fig. 7. Effect of agitation speed on $\mathrm{Ni}^{+2}$ removal percent ( $\mathrm{Co}=50 \mathrm{mg} / \mathrm{L}$, Time $=150 \mathrm{~min}, \mathrm{pH}=4$, and mass of GBW $=1 \mathrm{~g} / 100 \mathrm{ml})$

\section{d. Effect of the Dose of GBW}

The study of the mass of GBW that utilized for the removal of $\mathrm{Ni}^{+2}$ ions, was carried out using the various dosage of GBW range from $(0.2$ - 2) g. The effect of sorbent dose on the sorption of nickel by GBW was presented in Fig. 8. As illustrated in Fig.8, the nickel removal percent increased with increase of sorbent dose. The increase in the GBW dosage improved the availability of more effective sites for the sorption, thus making easier penetration of nickel ions to the sorption sites, [23]. Moreover, the final $\mathrm{pH}$ increase due to release the amounts of dissolved $\mathrm{Ca}^{+2}$ and other light metal alkalis in solution during the reaction between GBW and $\mathrm{Ni}^{+2}$ ions, [20].

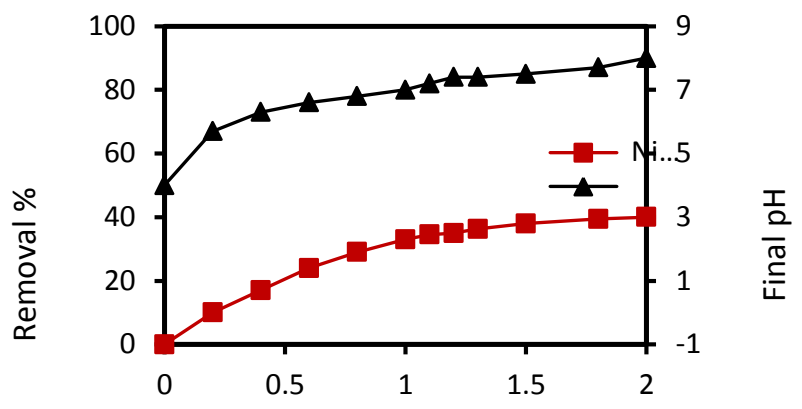

mass of sorbent $(\mathrm{g})$

Fig. 8. Effect of sorbent dose on $\mathrm{Ni}^{+2}$ removal percent (Co $=50 \mathrm{mg} / \mathrm{L}, \mathrm{pH}=4$, Time $=90 \mathrm{~min}$, and mass of $\mathrm{GBW}=$ $1 \mathrm{~g} / 100 \mathrm{ml})$

\subsection{Sorption Isotherms}

The sorption data for nickel is fitted with linearized equations of three isotherm models namely; Langmuir, Freundlich and Elovich. 
Accordingly, the empirical coefficients for each model were determined from the slope and intercept of linear plot using Microsoft Excel 2013 software. The isotherm graphical representations of these three models are shown in Fig. 9. All constants are presented in Table 1.

The value of $\mathrm{R}^{2}$ close to 1 denotes that the respective equation a good fits the experimental data, [27]. So, the Freundlich isotherm model was concluded to be preferred isotherms models for the experimental data.

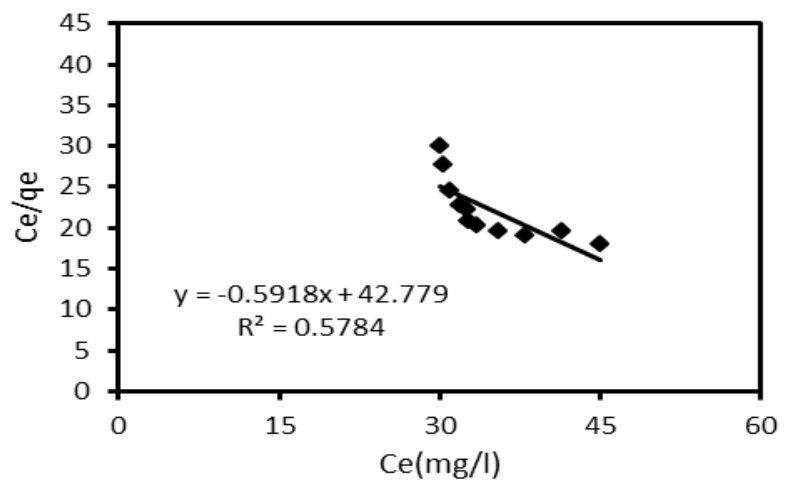

(a)

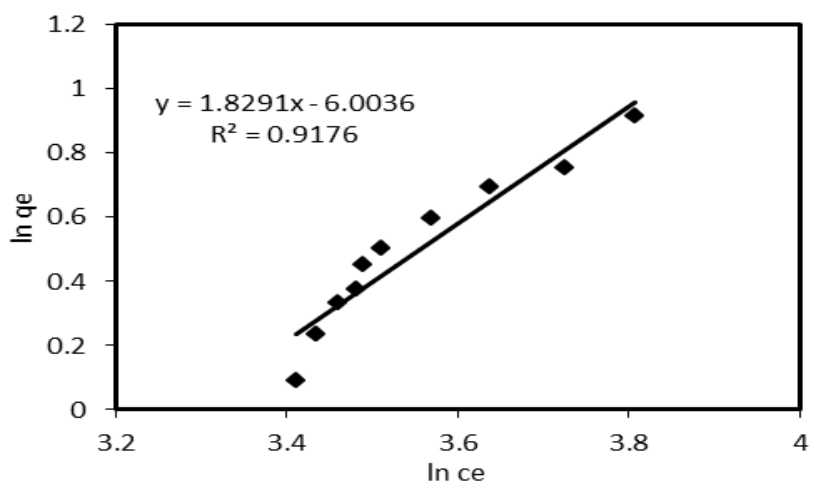

(b)

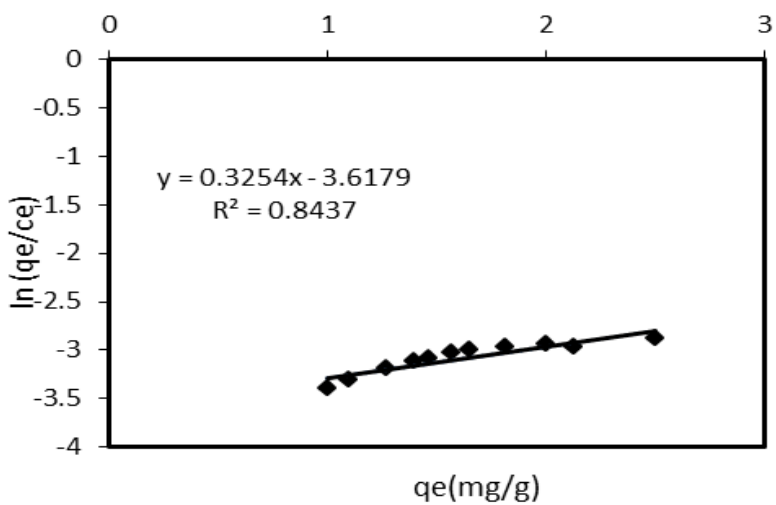

(c)

Fig. 9. Isotherm models plot: a. Langmuir isotherm model, b. Freundlich isotherm model, c. Elevich isotherm model
Table 1. Sorption isotherm constants with coefficients of determination for $\mathrm{Ni}^{+2}$ onto GBW

\begin{tabular}{lll}
\hline \multicolumn{1}{c}{ Isotherm model } & \multicolumn{1}{c}{ Parameters } & \multicolumn{1}{c}{$\mathrm{GBW}$} \\
\hline \multirow{3}{*}{ Langmuir } & $\mathrm{q}_{\mathrm{m}}(\mathrm{mg} / \mathrm{g})$ & -1.69 \\
& $\mathrm{~b}(1 / \mathrm{mg})$ & -0.014 \\
& $\mathrm{R}^{2}$ & 0.5784 \\
& $\mathrm{~K}_{\mathrm{F}}(1 / \mathrm{mg})$ & 0.00247 \\
Freundlich & $\mathrm{n}$ & 0.547 \\
& $\mathrm{R}^{2}$ & 0.9176 \\
Elovich & $\mathrm{q}_{\mathrm{m}}(\mathrm{mg} / \mathrm{g})$ & -3.07 \\
& $\mathrm{~K}_{\mathrm{E}}(1 / \mathrm{mg})$ & -0.00874 \\
& $\mathrm{R}^{2}$ & 0.8437 \\
\hline
\end{tabular}

\subsection{Kinetic Study}

To identify the type of sorption mechanism occurs, the kinetic equations namely pseudo-first -order and pseudosecond - order were utilized. It is clear from Fig. 10 and Table 2 that the reaction for GBW is pseudo-first -order because the value of the experimental qe was the closest to the qe calculated from the pseudo-first -order in compared with the pseudo-second - order model, irrespective to the amount of the correlation coefficient $\left(\mathrm{R}^{2}\right)$, so that the mechanisms will be physical sorption [29].

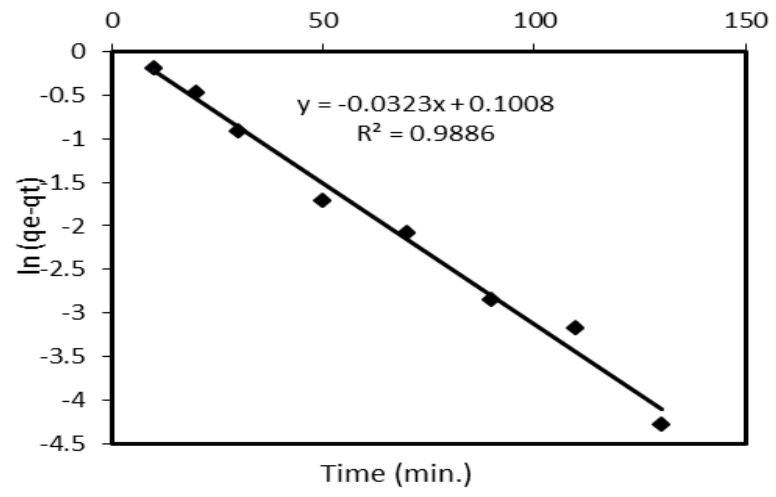

(a)

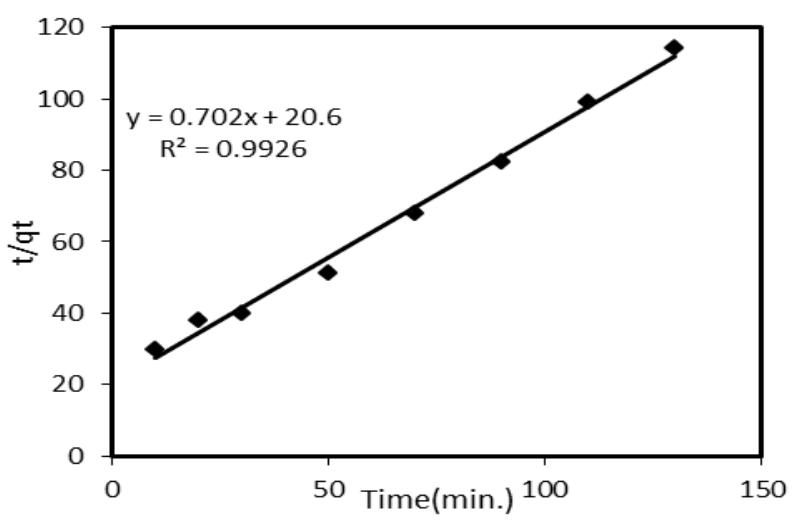

(b)

Fig. 10. The kinetic models for sorption $\mathrm{Ni}^{+2}$ onto GBW: a. Pseudo-first order reaction model, b. Pseudo-secondorder reaction model 
Table 2. The kinetic constants for the sorption of $\mathrm{Ni}^{+2}$ onto

\begin{tabular}{lllll}
\hline $\begin{array}{c}\text { qe (exp) } \\
(\mathrm{mg} / \mathrm{g})\end{array}$ & \multicolumn{2}{c}{$\begin{array}{c}\text { pseudo- first- } \\
\text { order }\end{array}$} & \multicolumn{2}{c}{$\begin{array}{c}\text { pseudo- second }- \\
\text { order }\end{array}$} \\
\hline & $\mathrm{K}_{1}(1 / \mathrm{min})$ & 0.0323 & $\mathrm{~K}_{2}\left(\mathrm{~g} / \mathrm{mg}^{*}\right.$ min $)$ & 0.024 \\
& & & & \\
& & & \\
& $\begin{array}{l}\text { qe (calc. }) \\
(\mathrm{mg} / \mathrm{g})\end{array}$ & 1.11 & $\begin{array}{l}\text { qe(calc. }) \\
(\mathrm{mg} / \mathrm{g})\end{array}$ & 1.42 \\
& $\mathrm{R}^{2}$ & 0.9886 & $\mathrm{R}^{2}$ & 0.9926 \\
\hline
\end{tabular}

\section{6- Conclusions}

Based on the results obtained from the experimental work, the following conclusions can be drawn:

- The granules of brick waste (GBW) material proved low effectiveness in removing nickel ions from aqueous solutions with removal percent of $39.4 \%$ at dose value of 1.8 sorbent according to the experimental conditions .

- The batch results indicated that several parameters including contact time, initial concentration, agitation speed, and granular brick waste dose affect the sorption process. The optimum values of these factors which provided maximum removal percent (39.4\%) of nickel with initial $\mathrm{pH}$ of 4 were $90 \mathrm{~min}, 50 \mathrm{mg} / \mathrm{l}$, $250 \mathrm{rpm}$, and $1.8 / 100 \mathrm{ml}$, respectively. The maximum sorption capacity for GBW (1.153mg/g )

- The isotherm study refers that the sorption data correlated well with Freundlich isotherm model which showed the highest value of the correlation coefficient $\left(\mathrm{R}^{2}=0.9176\right)$

- The kinetic study showed that the pseudo-first -order kinetic model was conform better than pseudo-second - order model kinetic model. This result clarify that physical sorption have been predominant in the sorption of $\mathrm{Ni}^{+2}$ ions using GBW.

\section{References}

[1] A. H., Sulaymon, B. A., Abid, \& J. A., Al-Najar "Removal of lead copper chromium and cobalt ions onto granular activated carbon in batch and fixed-bed adsorbers." Chemical Engineering Journal 155.3 (2009): 647-653.

[2] F. H. Kamar AL-Hamadani, "Removal of Nickel Ions Using A Biosorbent Bed (Laminaria saccharina) Algae", ijcpe, vol. 13, no. 4, pp. 47-55, Dec. 2012.

[3] P. V., Hemalatha, \& P. V. V. , Prasada Rao. "Adsorption batch studies on calcined brick powder in removing chromium and nickel ions." International Journal Advanced Research in Chemistry Science 1.6 (2014): 14-21.

[4] Y., Hannachi, \& A. , Hannachi. "The efficiency of the flotation technique for the removal of nickel ions from aqueous solution." Desalination and Water Treatment 6.1-3 (2009): 299-306.
[5] M. A., Abdullah, \& A. D. , Prasad. "Biosorption of nickel (II) from aqueous solutions and electroplating wastewater using tamarind (Tamarindus indica L.) bark. ," Australian Journal of Basic and Applied Sciences 4.8 (2010): 3591-3601.

[6] M., Hunsom, K., Pruksathorn, S., Damronglerd, H., Vergnes, \& P., Duverneuil. "Electrochemical treatment of heavy metals $(\mathrm{Cu} 2+, \mathrm{Cr} 6+, \mathrm{Ni} 2+)$ from industrial effluent and modeling of copper reduction." Water Research 39.4 (2005): 610-616.

[7] W., Qiu, \& Y. Zheng, "Removal of lead, copper, nickel, cobalt, and zinc from water by a cancrinitetype zeolite synthesized from fly ash." Chemical Engineering Journal 145.3 (2009): 483-488.

[8] F., Chang, J., Qu, R., Liu, X., Zhao, \& P., Lei. "Practical performance and its efficiency of arsenic removal from groundwater using Fe-Mn binary oxide." Journal of Environmental Sciences 22.1 (2010): 1-6.

[9] N., Boujelben, J., Bouzid, \& Z. , Elouear. "Adsorption of nickel and copper onto natural iron oxide-coated sand from aqueous solutions: study in single and binary systems." Journal of hazardous materials 163.1 (2009): 376-382.

[10] M. Q., Jiang, X. Y., Jin, X. Q., Lu, \& Z. L. , Chen. "Adsorption of $\mathrm{Pb}$ (II), Cd (II), Ni (II) and $\mathrm{Cu}$ (II) onto natural kaolinite clay." Desalination 252.1-3 (2010): 33-39.

[11] S. C. , Dehou, M., Wartel, P., Recourt, B., Revel, J., Mabingui, A., Montiel, \& A. ,Boughriet "Physicochemical, crystalline and morphological characteristics of bricks used for ground waters purification in Bangui region (Central African Republic)." Applied Clay Science 59 (2012): 69-75.

[12] H. A., Aziz, M. N., Adlan, \& K. S., Ariffin. "Heavy metals (Cd, Pb, Zn, Ni, $\mathrm{Cu}$ and $\mathrm{Cr}$ (III)) removal from water in Malaysia: post treatment by high quality limestone." Bioresource technology 99.6 (2008): 1578-1583.

[13] R., Djeribi, \& O. , Hamdaoui. "Sorption of copper (II) from aqueous solutions by cedar sawdust and crushed brick." Desalination 225.1-3 (2008): 95112.

[14] N., Priyantha, \& A. , Bandaranayaka. "Interaction of $\mathrm{Cr}$ (VI) species with thermally treated brick clay." Environmental Science and Pollution Research 18.1 (2011): 75-81.

[15] A. R., Kul, \& H., Koyuncu. "Adsorption of $\mathrm{Pb}$ (II) ions from aqueous solution by native and activated bentonite: kinetic, equilibrium and thermodynamic study." Journal of Hazardous Materials 179.1-3 (2010): 332-339.

[16] A. A., Inyinbor, F. A., G. A. Adekola, \& Olatunji. "Kinetics, isotherms and thermodynamic modeling of liquid phase adsorption of Rhodamine B dye onto Raphia hookerie fruit epicarp." Water Resources and Industry 15 (2016): 14-27. 
[17] N., Ayawei, A. N., Ebelegi, \& D. , Wankasi. "Modelling and interpretation of adsorption isotherms." Journal of Chemistry 2017 (2017).

[18] A. H., Sulaymon, A. A., Faisal, \& Z. T. , Abd Ali "Performance of granular dead anaerobic sludge as permeable reactive barrier for containment of lead from contaminated groundwater." Desalination and Water Treatment 56.2 (2015): 327-337.

[19] S. S., Gupta, \& K. G. , Bhattacharyya. "Kinetics of adsorption of metal ions on inorganic materials: a review." Advances in colloid and interface science 162.1-2(2011): 39-58.

[20] I., Jelić, M., Šljivić-Ivanović, S., Dimović, D., Antonijević, M., Jović, M., Mirković, \& I., Smičiklas. "The applicability of construction and demolition waste components for radionuclide sorption." Journal of cleaner production 171 (2018): 322-332.

[21] S., Hussain, S., Gul, S., Khan, H. U., Rehman, M., Ishaq, A. , Khan, \& Z. U. Din. "Removal of $\mathrm{Cr}$ (VI) from aqueous solution using brick kiln chimney waste as adsorbent." Desalination and Water Treatment 53.2 (2015): 373-381.

[22] F., Kooli, L., Yan, R., Al-Faze, \& A., AlSehimi. "Removal enhancement of basic blue 41 by brick waste from an aqueous solution." Arabian Journal of Chemistry 8.3 (2015): 333-342.

[23] H., Panda, N., Tiadi, M., Mohanty \& C. R. Mohanty "Studies on adsorption behavior of an industrial waste for removal of chromium from aqueous solution." south african journal of chemical engineering 23 (2017): 132-138

[24] K. G., Akpomie, F. A., Dawodu, \& K. O. , Adebowale "Mechanism on the sorption of heavy metals from binary-solution by a low cost montmorillonite and its desorption potential." Alexandria Engineering Journal 54.3 (2015): $757-$ 767.

[25] M., Martinez, N., Miralles, S., Hidalgo, N., Fiol, I., Villaescusa, \& J. , Poch. "Removal of lead (II) and cadmium (II) from aqueous solutions using grape stalk waste." Journal of Hazardous Materials 133.1-3 (2006): 203-211.

[26] M., Horsfall Jnr, \& A. I. Spiff. "Studies on the effect of $\mathrm{pH}$ on the sorption of $\mathrm{Pb} 2+$ and $\mathrm{Cd} 2+$ ions from aqueous solutions by Caladium bicolor (Wild Cocoyam) biomass." Electronic Journal of Biotechnology 7.3 (2004): 14-15.

[27] M. A. O., Badmus, T. O. K., Audu, \& B. U. Anyata. "Removal of lead ion from industrial wastewaters by activated carbon prepared from periwinkle shells (Typanotonus fuscatus)." Turkish journal of engineering and environmental sciences 31.4 (2007): 251-263.

[28] P. S., Kumar, \& R. , Gayathri. "Adsorption of $\mathrm{Pb} 2+$ ions from aqueous solutions onto bael tree leaf powder: isotherms, kinetics and thermodynamics study." Journal of Engineering Science and Technology 4.4 (2009): 381-399.
[29] L. C., Edomwonyi-otu, S. O., Gabor, O. A., Idowu, \& S. G. ,Bawa "Kinetics of Adsorption of Nickel Ion on Kankara Kaolinite" Leonardo Electronic Journal of Practices and Technologies 22 (2013): 83-92. 


\section{إعادة استخدام نفايات الطابوق كمادة رخيصة لإزالة ايونات النيكل من المحاليل المائية طيبه مهاوش و زياد عبد علي جامعة بغداد, كلية الهندسة, قسم الهندسة البيئية}

Ni ${ }^{+2}$ تمت دراسة امكانية تطبيق حبيبات مخلفات الطوب (GBW) كمواد منخفضة التكلفة لإزالة أيونات من المحاليل المائية. تم تحديد خصائص GBW من خلال العديد من الفحوصات مثل حيود الأشعة السينية ، الأشعة السينية المشتنة للطاقة (EDD) (لمDX) ، المجهر الإكتروني المسح الضوئي (SEM) ، والمساحة السطحية. في اختبارات الأفعات ، تم فحص تأثير العديد من العوامل بما في ذلك وقت الاتصال والتركيزالابتدائي وسرعة الرج وجرعة GBW. كانت أفضل قيم المعاملات التي وفرت أقصى كفاءة إزالة

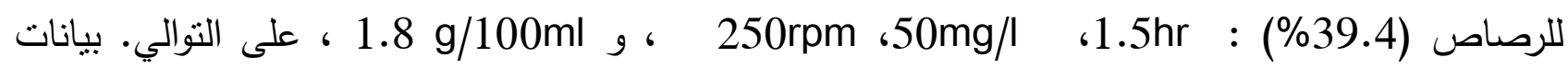
الامتصاص التي تم الحصول عليها من خلال تجارب الأفعات التي خضعت لنماذج isotherm الثلاثة

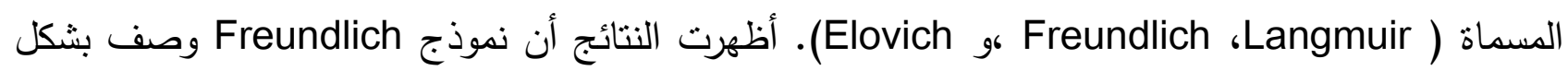
جيد بيانات الامتصاص (=R2 0.9176) بالمقارنة مع النماذج الأخرى. وقد تم تحليل البيانات الحركية pseudo- باستخدام نموذجين : pseudo-first-order و ). تم ايجاد ان يمثل جيدا البيانات التجربيية. first-order الكلمات الدالة: الامتصاص, Ni + 2 , نفايات القرميد, مياه الصرف الصحي 